\title{
Regeneration of five Combretaceae species along a latitudinal gradient in Sahelo-Sudanian zone of Burkina Faso
}

\author{
Fidèle Bognounou ${ }^{1 *}$, Mulualem Tigabu $^{2}$, Patrice SAVAdogo $^{2,3}$, Adjima ThiOMBiAno $^{1}$, \\ Issaka Joseph Boussim ${ }^{1}$, Per Christer ODEN ${ }^{2}$, Sita GuINKO $^{1}$ \\ ${ }^{1}$ Université de Ouagadougou, Unité de Formation et Recherche en Sciences de la Vie et de la Terre, 03 B.P. 7021, Ouagadougou, Burkina Faso \\ ${ }^{2}$ Swedish University of Agricultural Sciences, Faculty of Forest Sciences, Southern Swedish Forest Research Centre, \\ PO Box 101, 23053 Alnarp, Sweden \\ ${ }^{3}$ Centre National de la Recherche Scientifique et Technologique, Institut de l'Environnement et de Recherches Agricoles, \\ Département Productions Forestières, 03 BP 7047, Ouagadougou 03, Burkina Faso
}

(Received 5 January 2009; accepted 16 June 2009)

Keywords:

African savanna /

coppice /

seedling sprout /

suckering /

resprouting /

restoration

\begin{abstract}
- Seedling density and the regeneration mechanisms of five tree species, Anogeissus leiocarpa, Combretum aculeatum, Combretum micranthum, Combretum nigricans, and Pteleopsis suberosa were investigated in relation to latitudinal gradient across the Sahelo-Sudanian zone of West Africa.

- Data were collected on 461 quadrats $(2 \mathrm{~m} \times 5 \mathrm{~m}$ ) laid out every $30 \mathrm{~m}$ on transect lines through Combretaceae communities at four latitudinal positions. Regeneration mechanisms were determined by excavating the below ground root system and assessing basal and aerial sprouts.

- The results showed a significant species $\times$ latitudinal position effect on the total density of seedling populations, and the density of single- and multi-stemmed individuals $(p<0.001)$. C. aculeatum and $C$. micranthum were abundant in the North-Sahelian sector, C. nigricans and P. suberosa in the Sudanian sector and A. leiocarpa across a wide range from the South-Sahelian to South-Sudanian sectors. In general, $58 \%$ of the seedlings were regenerated asexually (as coppice, water sprout, layer, and root sucker) while $42 \%$ were sexual recruits (as true seedling and seedling sprouts). The proportion of vegetatively propagated seedlings increased with increasing latitude for all species except $C$. $m i$ cranthum, for which a clear decreasing trend was observed. The relative importance of the different regeneration mechanisms varied among species: seedling sprouts were important for A. leiocarpa, C. aculeatum and C. nigricans, coppice for C. micranthum and sucker for P. suberosa

- The significant interaction observed between species and latitudinal position highlights the importance of accurate species-site matching to ensure successful restoration of degraded areas in the Sahelo-Sudanian zone. Inter-species differences in regeneration mechanism could be related to their biology and ecological adaptation to the site-specific biotic and abiotic factors.
\end{abstract}

Résumé - La régénération de cinq espèces de Combretaceae le long d'un gradient latitudinal en zone sahélo-soudanienne du Burkina Faso.

- La densité de semis et les mécanismes de régénération de cinq espèces d'arbres, Anogeissus leiocarpa, Combretum aculeatum, Combretum micranthum, Combretum nigricans, et Pteleopsis suberosa ont été étudiés par rapport au gradient latitudinal dans la zone sahélo-soudanienne de l'Afrique occidentale.

- Les données ont été recueillies sur 461 quadrats $(2 \mathrm{~m} \times 5 \mathrm{~m})$ disposés tous les $30 \mathrm{~m}$ sur des lignes de transects à travers les communautés de Combretaceae dans quatre positions latitudinales. Les mécanismes de régénération ont été déterminés par l'excavation du sol en dessous du système racinaire et par l'évaluation des pousses basales et aériennes.

- Les résultats ont montré l'importance de l'effet position latitudinale $\times$ espèces sur la densité totale des populations de semis, et la densité des individus à fût simple ou multiples $(p<0,001)$. $C$. aculeatum et $C$. micranthum étaient abondants dans le secteur nord-sahélien, $C$. nigricans et $P$. suberosa dans le secteur Soudanien et A. leiocarpa dans une large aire du secteur Sud-sahélien au secteur

*Corresponding author: Fidele.Bognounou@genfys.slu.se; fidelebognounou@yahoo.fr 
sud-soudanien. En général, 58 \% des plants ont été régénérés par voie végétative (taillis, gourmands, marcottes et drageons), alors que $42 \%$ étaient des recrues sexuées (vrais semis et baliveaux). La proportion de jeunes plants issus de la multiplication végétative s'est accrue avec l'augmentation de la latitude, pour toutes les espèces, sauf $C$. micranthum, pour laquelle une tendance claire à la baisse a été observée. L'importance relative des différents mécanismes de régénération a varié selon les espèces : les baliveaux sont importants pour A. leiocarpa, C. aculeatum et $C$. nigricans, les taillis pour C. micranthum et les drageons pour P. suberosa.

- L'interaction significative observée entre les espèces et la position en latitude met en évidence l'importance de veiller à une bonne correspondance des espèces et des sites pour assurer le succès de la restauration des terres dégradées dans la zone sahélo-soudanienne. Des différences interspécifiques dans les mécanismes de régénération pourraient être liées à leur biologie et à leur adaptation écologique aux spécificités stationnelles des facteurs biotiques et abiotiques.

\section{INTRODUCTION}

Tree regeneration processes (e.g. seed germination, seedling establishment, population change and spatial distribution) can be influenced by many factors, including interval of seed production, seed dispersal, seed quality, light conditions, temperature, slope gradient, and soil moisture availability (Vieira and Scariot, 2006). Seed germination and seedling survival are probably the most critical stages in the life history of plant populations (Kitajima and Fenner, 2000) since the recruitment of seedlings determines the composition of the future population (Vieira and Scariot, 2006). Species distribution, colonization capability and range shifts are, therefore, partially determined by limitations on progeny viability (Weltzin and McPherson, 1999). In species with a wide distribution, a suitability gradient is found in habitats along latitudinal gradient; this is the case for a wide range of tree taxa.

Latitudinal gradient is a surrogate for a number of primary environmental factors. It ultimately depends on geographic, biotic, abiotic and stochastic forces (Schemske, 2002), which affect the geometry, internal structure, and location of species ranges in ecological or evolutionary time. Ecologists have attempted to explain the latitudinal gradient by considering factors that vary with latitude. Many explanations invoke recent climate or related factors such as temperature, rainfall, solar input, seasonality and productivity, which interact and are correlated with each other (Hawkins et al., 2003; Willig et al., 2003). Plant recruitment and diversity are found to mirror the primary explanatory variables associated with latitudinal gradient, which are likely to vary continuously from lower to higher latitudes (Gaston, 2007). Thus, in the tropics, plants occurring at high latitude are likely to face particularly harsh environmental conditions that limit seedling emergence and survival (Cecccon et al., 2006; Moles et al., 2004), mainly due to water stress (Poorter and Markesteijn, 2008; Slot and Poorter, 2007). However, local adaptation acting upon seedling emergence and seedling survival and growth may help partially to counteract environmental limitations, allowing local persistence of seedling population. Moving from high to low latitude in the tropics, average seedling density increases (Stevens, 1989), and some species may use different regeneration mechanisms to survive at the edge of their distribution area (Catinot, 1994). Understanding species recruitment along latitudinal gradient may, thus, provide valuable information on the ecological significance of plasticity of plant in response to varying environmental conditions and insight to the role adaptation in regeneration may play in their long-term local persistence.

Studies on tree communities in the Sahelo-Sudanian zone have shown that most tree species regenerate both sexually and asexually (Bationo et al., 2005; Bellefontaine, 2005; Ky-Dembele et al., 2007). The potential of having both reproductive modes may maximize individual species fitness by combining the advantages of both regeneration mechanisms; particularly since most tropical species have seeds that do not form long-lived soil seed banks (Vázquez-Yanes and Orozco-Segovia, 1993). Vegetative regeneration seems to be advantageous over sexual regeneration for many species in conditions where climate becomes harsh, presumably because vegetative shoots may take advantage of the extensive root system and the substantial storage of metabolites in the remaining part of the plant. Moreover the low humidity in dry climate restricts water and nutrient availability for survival and growth of young succulent seed-origin seedlings.

Combretaceae constitutes one of the most specious families in most Sudanian savanna-woodland of West Africa and particularly in Burkina Faso (Fontes and Guinko, 1995; Thiombiano, 2005). Species in this family have a wide ecological distribution and high socio-economic importance for the reduction of poverty in the region. The challenges for sustainable use can be met only if efforts are made to maintain the population and to restore deforested and degraded areas. Thus, knowledge of the regeneration pathways of each species and their suitability for specific site conditions is crucial for the restoration of woodland ecosystem, since each region in dry areas requires its own set of suitable management strategies (Khurana and Singh, 2001; Vieira and Scariot, 2006). To the best of our knowledge, little information is available on the natural regeneration mechanism and seedling populations of these species in relation to latitudinal gradient. Most studies that have investigated the natural regeneration of Sahelo-Sudanian woody species have tended to focus on regeneration mechanisms after selective logging (Ky-Dembele et al., 2007), spatial distribution and germination of selected species (Bationo et al., 2005), and seedling and sapling population dynamics under different management regimes (Zida et al., 2007; 2009). Therefore, this study was conducted to examine the natural regeneration of five Combretaceae species; i.e. Anogeissus leiocarpa (DC.) Guill. et Perr. Combretum aculeatum Vent., Combretum micranthum 


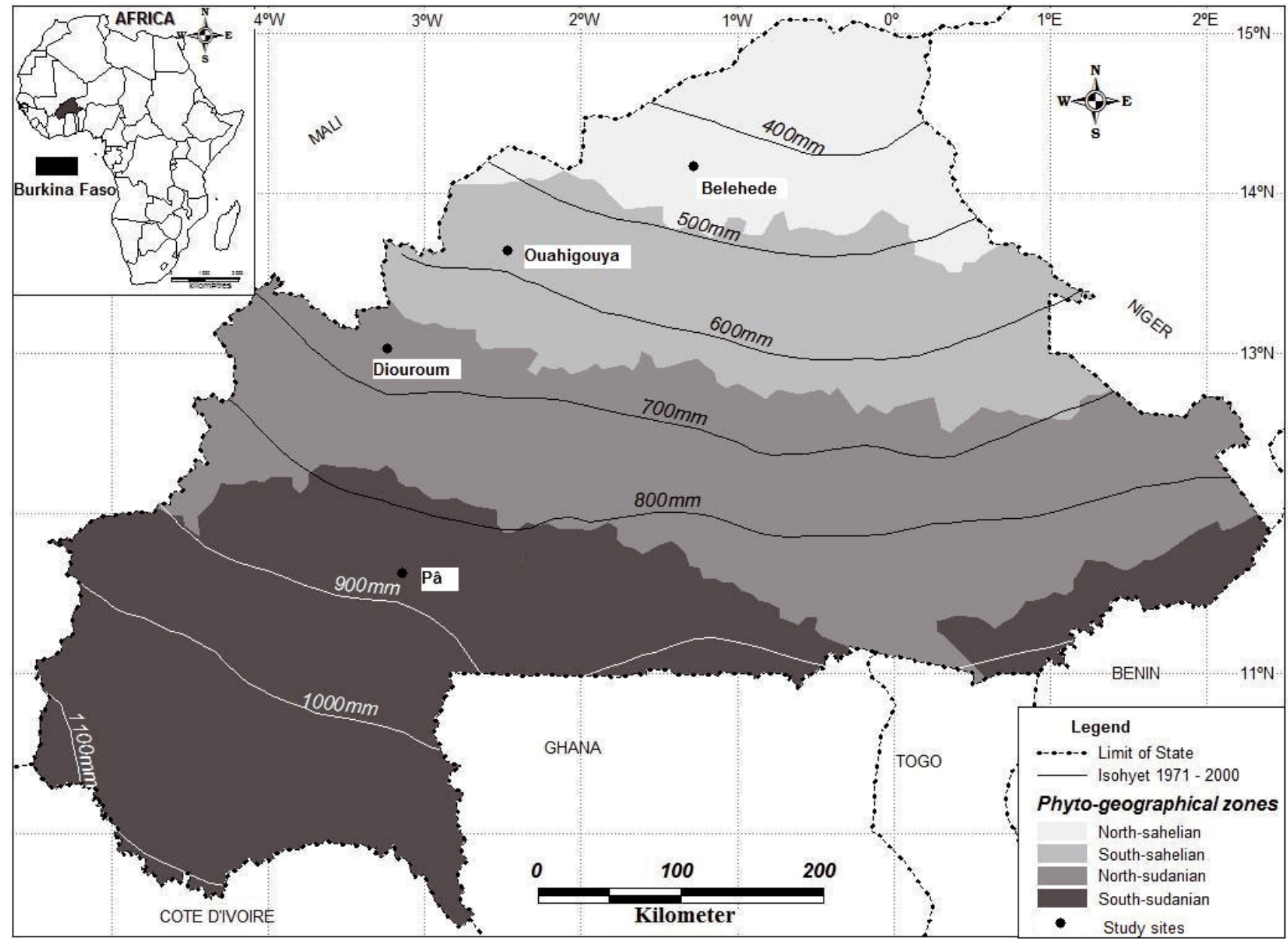

(Source: Readapted April 2007 by CTIG/INERA/Burkina Faso after Fontes \& Guinko 1995 and Direction of the National Meteorology.)

Figure 1. Phytogeographical map of Burkina Faso with isohyets and location of the study sites.

G. Don, Combretum nigricans Lepr. ex Guill. \& Perr., and Pteleopsis suberosa Engl. \& Diels) along a latitudinal gradient that corresponds to four phytogeographical units in Burkina Faso. We focused on species within the same family to control for phylogenic variation. The hypotheses of the study were:

(1) seedling population density and seedling morphology vary along a latitudinal gradient due to pronounce climate variation, soil fertility and moisture variability;

(2) clonal expansion is the dominant regeneration mechanism at high latitude due to harsh environmental conditions that limit recruitment of seed-origin seedlings.

\section{MATERIAL AND METHODS}

\subsection{Study sites}

The study was carried out at four sites along a latitudinal gradient in Western Burkina Faso, West Africa (Fig. 1). The study sites were Belehede $\left(14^{\circ} 06^{\prime} \mathrm{N}\right.$ and $\left.1^{\circ} 12^{\prime} \mathrm{W}\right)$, Ouahigouya $\left(13^{\circ} 32^{\prime} \mathrm{N}\right.$ and $\left.2^{\circ} 22^{\prime} \mathrm{W}\right)$, Diouroum $\left(12^{\circ} 58^{\prime} \mathrm{N}\right.$ and $\left.3^{\circ} 08^{\prime} \mathrm{W}\right)$ and Pâ $\left(11^{\circ} 35^{\prime} \mathrm{N}\right.$ and $3^{\circ} 14^{\prime} \mathrm{W}$ ) all located at about $300 \mathrm{~m}$ above sea level. At all sites, the vegetation is strongly seasonal and virtually all woody species are deciduous, most herbs are either annual or die back to the ground each dry season. Species in the Combretaceae and Mimosaceae families dominate the woody vegetation in these areas. Phytogeographically, the study sites are located in the following sectors defined by Fontes and Guinko (1995). The North-Sahelian sector (Belehede) has annual rainfall between $400-500 \mathrm{~mm}$, with 30-40 rainy days per year. The most frequently encountered soils are solonetz (Driessen et al., 2001) with overlying sandy-clay material. The common woody species are Grewia tenax (Forssk.) Fiori, Acacia senegal Willd., C. aculeatum, C. micranthum and A. leiocarpa. The grass layer is dominated by Aristida sp., Cenchrus prieuri (Kunth) Maire and Tetrapogon cenchriformis (A. Rich.) Pilg. The SouthSahelian sector (Ouahigouya) has a mean annual rainfall between 500 and $600 \mathrm{~mm}$, with 40-50 rainy days per year. The most frequently encountered soils are tropical ferruginous soils, poorly evolved eroded soils overlying gravels. The common species are C. aculeatum, C. micranthum, C. nigricans, Balanites aegyptiaca var. ferox (Poir.) 
Table I. Description of the different regeneration mechanisms.

\begin{tabular}{ll}
\hline Regeneration mechanism & \multicolumn{1}{c}{ Characteristics } \\
\hline True seedling & An individual of seed origin that was never affected by shoot dieback \\
Seedling sprout & An individual of seed origin that was affected by shoot dieback, but resprouted from the root collar of the seedling \\
Root sucker & An individual arising vertically from superficial lateral root \\
Coppice & An individual arising from stumps of cut mature tree in response to logging or non-logging disturbances and \\
& which root diameter exceeds $10 \mathrm{~cm}$ \\
Water sprout & An individual developed from the base of alive mature tree \\
Layer & An individual developed from low hanging lateral branch layers and arising from adventitious buds \\
\hline
\end{tabular}

DC., A. leiocarpa, Boscia salicifolia Oliv., Commiphora africana var. glaucidula (Engl.) J.B. Gillett and Pterocarpus lucens Lepr. ex Guill. \& Perr. The main grass species were Aristida hordeacea Hochst. ex Steud., Cenchrus sp. and Chloris lamproparia Stapf. The North-Sudanian sector (Diouroum) has a mean annual rainfall between 600 and $700 \mathrm{~mm}$ and 40-70 rainy days per year. The most frequently encountered soils are tropical ferruginous soils, poorly to completely leached. The common woody species are Acacia seyal Delile, C. micranthum, C. glutinosum, C. nigricans, Guiera senegalensis, A. leiocarpa and $P$. suberosa. The herbaceous vegetation is dominated by Andropogon pseudapricus Stapf, Loudetia togoensis (Pilg.) C.E. Hubb., Andropogon gayanus Kunth, Elionurus elegans Kunth and Cymbopogon schoenanthus Spreng. The South-Sudanian sector (Pâ) has a mean annual rainfall between 800 and $900 \mathrm{~mm}$, with 70-90 rainy days per year. The most frequently encountered soils are hydromorphic mineral to pseudogley soils. The common woody species are A. leiocarpa, Burkea africana Hook., Daniellia oliveri (Rolfe) Hutch. \& Dalziel, Diospyros mespiliformis Hochst. ex A.DC., C. glutinosum, C. nigricans, Isoberlinia doka Craib \& Stapf and P. suberosa. The main herbaceous species were A. gayanus, Diheteropogon amplectens (Nees) Clayton, Loudetia simplex (Nees) C.E. Hubb. and Vetiveria nigritana Stapf.

\subsection{Studied species}

Five species were selected for the study based on their large ecological distribution and their importance in pharmacopeia, wood fuel, construction material, handicrafts, the production of agricultural tool handles, utensils and household furniture (Thiombiano, 2005). A. leiocarpa is a medium-size tree (7-18 $\mathrm{m}$ in height) with a wide ecological distribution ranging from the borders of the Sahara up to the outlying humid tropical forests. It grows in both the Sudanian and Sahelian sectors, fringing forests and semi-arid savanna areas around swamps, and in valleys and forest galleries, where it usually forms pure, dense and closed stands. C. aculeatum is a scrambling shrub, either $0.5-4 \mathrm{~m}$ tall with virgate branches, or up to $8 \mathrm{~m}$ with scandent branches. It is widespread in dry areas, in bushland, woodland, savanna, and wooded grassland. It is often found along rivers and on rocky slopes. It is a sub-Sahelian dry zone species that is adapted to a wide edaphic condition, growing on alluvial soils as well as sandy, stony or clay soils. C. micranthum is a small tree, shrub or liana (4-10 $\mathrm{m}$ in height). It may reach a height of $20 \mathrm{~m}$ by twining around the branches of nearby trees. It grows in the Sahelian and the North-Sudanian sectors. It is a savanna plant found on dry sites, sandstone, clay, laterite, crystalline rocks, and skeletal soils. It is often gregarious and locally abundant, and is often found in pure, dense stands. C. nigricans is either a tree or a shrub, 4-12 $\mathrm{m}$ tall, with a dense, rounded crown. It grows in the South Sahelian and the Sudanian sectors. It is very common, locally abundant and gregarious. It is found in savanna and dry forests of the Guinean and Sudanian regions, usually on loamy or clay soils, but also on sandstone, sandy or rocky soils. $P$. suberosa is a shrub, 4-7 $\mathrm{m}$ tall. It is present in the Guinean and Sudanian regions. It grows in the Sudanian sector in deciduous woodland and wooded grassland on clay soils, sandstone and sandy or rocky soils.

\subsection{Data collection}

The seedling population survey was conducted following an unbalanced design scheme, including factorial combination of four sites along the latitudinal gradient and species. A total of 461 quadrats (North Sahelian sector 66, South Sahelian sector 111, North Sudanian sector 176 and South Sudanian sector 108), measuring $2 \times 5 \mathrm{~m}$ and spaced about $30 \mathrm{~m}$ apart, were laid out along transect lines through Combretaceae communities. The seedling inventory was carried out during the wet season (August 2007) to avoid missing seedlings that shed their leaves or die back during the dry season. The term "seedling" refers to woody plantlet with a shoot height up to $100 \mathrm{~cm}$ irrespective of the regeneration mechanism (Ky-Dembele et al., 2007). A seedling was considered to be multi-stemmed when it had more than one stem emerging from the base and fulfilled the above size criteria; otherwise it was considered to be a singlestemmed individual. Within each quadrat, the following parameters were recorded: number of individual seedlings per species and number of stems per individual. During the inventory, the different regeneration mechanisms were determined by excavating the below ground system and assessing basal and aerial sprouts. Accordingly, seedlings were classified into six regeneration mechanisms as true seedlings, seedling sprouts, water sprouts, coppices, root suckers and layers following previous study (Tab. I). True seedling and seedling sprout represent sexual regeneration while coppice, water sprouts, root suckers and layers represent asexual regeneration. In the case of vegetatively reproduced seedling, a clonal colony or genet (a group of genetically identical individuals that have grown in a given location, all originating vegetatively from a single mother trunk) was considered as one individual.

\subsection{Statistical analyses}

For each species, total seedling density, and density of multi- and single-stemmed individuals were computed and analyzed with generalized linear models using penalized quasi-likelihood with Poisson errors in order to account for non-normal errors and the increasing of 
Table II. Effects of latitudinal position, species and interaction on total density of seedling populations (TS), single-stemmed (SS) and multistemmed (MS) seedling density of five Combretaceae species in the Sahelo-Sudanian zone of Burkina Faso, West Africa.

\begin{tabular}{|c|c|c|c|c|c|c|c|}
\hline & \multicolumn{3}{|c|}{$\mathrm{TS}$} & \multicolumn{2}{|c|}{$\mathrm{SS}$} & \multicolumn{2}{|l|}{ MS } \\
\hline & $\mathrm{df}$ & $\mathrm{F}$ & $\mathrm{P}$ & $\mathrm{F}$ & $\mathrm{P}$ & $\mathrm{F}$ & $\mathrm{P}$ \\
\hline Site & 3 & 0.374 & 0.773 & 0.987 & 0.432 & 0.395 & 0.759 \\
\hline Species & 4 & 0.680 & 0.619 & 1.594 & 0.239 & 0.123 & 0.971 \\
\hline Sites $\times$ Species & 12 & 25.170 & $<0.001$ & 24.916 & $<0.001$ & 15.260 & $<0.001$ \\
\hline Error & 2285 & & & & & & \\
\hline
\end{tabular}

variances with increasing means that are associated with count data (Crawley, 2005). The relative importance of the different regeneration mechanisms, computed as the proportion of the number of seedlings in a given category of regeneration mechanism to the total number of seedlings of a given species, were analyzed with generalized linear models using penalized quasi-likelihood with Binomial errors, thereby accounting for the non-normal errors and the inconstancy of the variance that are associated with proportion data. Latitudinal position and species were treated as categorical fixed and random factors, respectively in order to account for the natural variability in the occurrence of species along the latitudinal gradient. The linear models used in the analysis were:

$$
N_{i s k} \sim P\left(\exp \left(\mu+\alpha_{s}+\beta_{k}+\gamma_{s k}\right)\right)
$$

and

$$
Y_{i s k} \sim \operatorname{Binom}\left(\left(\mu+\alpha_{s}+\beta_{k}+\gamma_{s k}\right) / 1+\exp \left(\mu+\alpha_{s}+\beta_{k}+\gamma_{s k}\right)\right)
$$

where $N_{i s k}$ is the count of seedlings of species $s$ in the $i$ th quadrat at site $k, P$ denotes the Poisson distribution, $Y_{i s k}$ denotes the proportion of seedling of species $s$ in the $i$ th quadrat at site $k$ that belong to a given regeneration mechanism, Binom denotes the Binomial distribution and $\mu, \alpha_{s}, \beta_{k}$ and $\gamma_{s k}$ are the parameters of the models. The magnitude of the effect of latitudinal position and species was determined by a statistic known as partial eta squared $\left(\eta_{p}^{2}\right)$, and the effect was considered as small, moderate or large if the value of this statistic was $0.01,0.06$ or 0.14 , respectively (Cohen, 1988). When a significant difference was detected, a pair-wise comparison was made using Tukey's test at the 5\% level of significance. All statistical analyses were performed with the R statistical software ( $\mathrm{R}$ development Core Team, 2006). The MASS package was used to calculate the generalized linear models using penalized quasi-likelihood estimates. The car package was used to perform the ANOVA using the type III sum of squares for non orthogonal design. The gplots package was used to draw the graphics.

\section{RESULTS}

\subsection{Seedling population structure}

Total seedling density did not differ significantly with respect to latitudinal position (sites) and species (Tab. II). However the site $\times$ species interaction effect was significant $(p<0.001)$, with large magnitude of effect $\left(\eta_{p}^{2}=0.117\right)$. With regard to seedling morphology, no variation in density of single- and multi-stemmed seedlings in relation to latitudinal position and species was found ( $p>0.05$ in all cases). However there was a highly significant (with $\eta_{p}^{2}=0.117$ and $\eta_{p}^{2}=0.074$ for single- and multi-stemmed, respectively) interaction effect of site $\times$ species for both single- and multistemmed seedlings density (Tab. II). The total seedling density was substantially high for $C$. aculeatum and C. micranthum in the North-Sahelian sector while that of $C$. nigricans and $P$. suberosa were abundant in Sudanian sector (Fig. 2A). A. leiocarpa seedlings occurred across a wide range from the South-Sahelian through North-Sudanian to South-Sudanian sectors. The density of multi-stemmed (Fig. 2B) and singlestemmed (Fig. 2C) individuals across the latitudinal gradient followed the same pattern as the total seedling density for all species, albeit differences in actual magnitude.

\subsection{Regeneration mechanism}

The proportion of sexual and asexually regenerated seedlings did not differ among latitudinal position and species, but the site $\times$ species interaction effect was significant (Tab. III). Considering all species and latitudinal positions together, $58 \%$ of the seedlings were regenerated asexually (as coppice, water sprout, layer, and root sucker) while $42 \%$ were sexual recruits (as true seedling and seedling sprouts). For A. leiocarpa and C. nigricans, asexual regeneration appeared to be the dominant mechanism in the Sahel while sexual regeneration was the dominant mechanism in the Sudanian sector (Fig. 3). For C. aculeatum, sexual regeneration was the predominant mechanism across the latitudinal gradient from the Sahel to north-Sudanian sector compared to asexual recruitment. For C. micranthum, asexual recruitment was the dominant mechanism of regeneration in the north-Sahelian and north-Sudanian sectors compared with other sites. Asexual recruitment was the exclusive mechanism of regeneration of $P$. suberosa in the Sudanian sector.

A highly significant site $\times$ species interaction effect was also observed for the relative importance of different regeneration mechanisms (Tab. IV), but no main effects of species and site $(p>0.05)$ except for the proportion of coppice which differed between species $(p=0.005)$. The proportion of coppices was high for A. leiocarpa $(6.91 \pm 0.92 \%)$ followed by $C$. micranthum $(4.11 \pm 0.76 \%)$ compared with the other studied species which had less than $1 \%$ coppices. The relative importance of the different regeneration mechanisms pooled for all sites varied for each species (Fig. 4). Seedling sprout was the most important mechanism for A. leiocarpa $(40 \%)$, C. aculeatum (65\%) and C. nigricans (51\%) while water sprout was important for C. micranthum (36\%). 

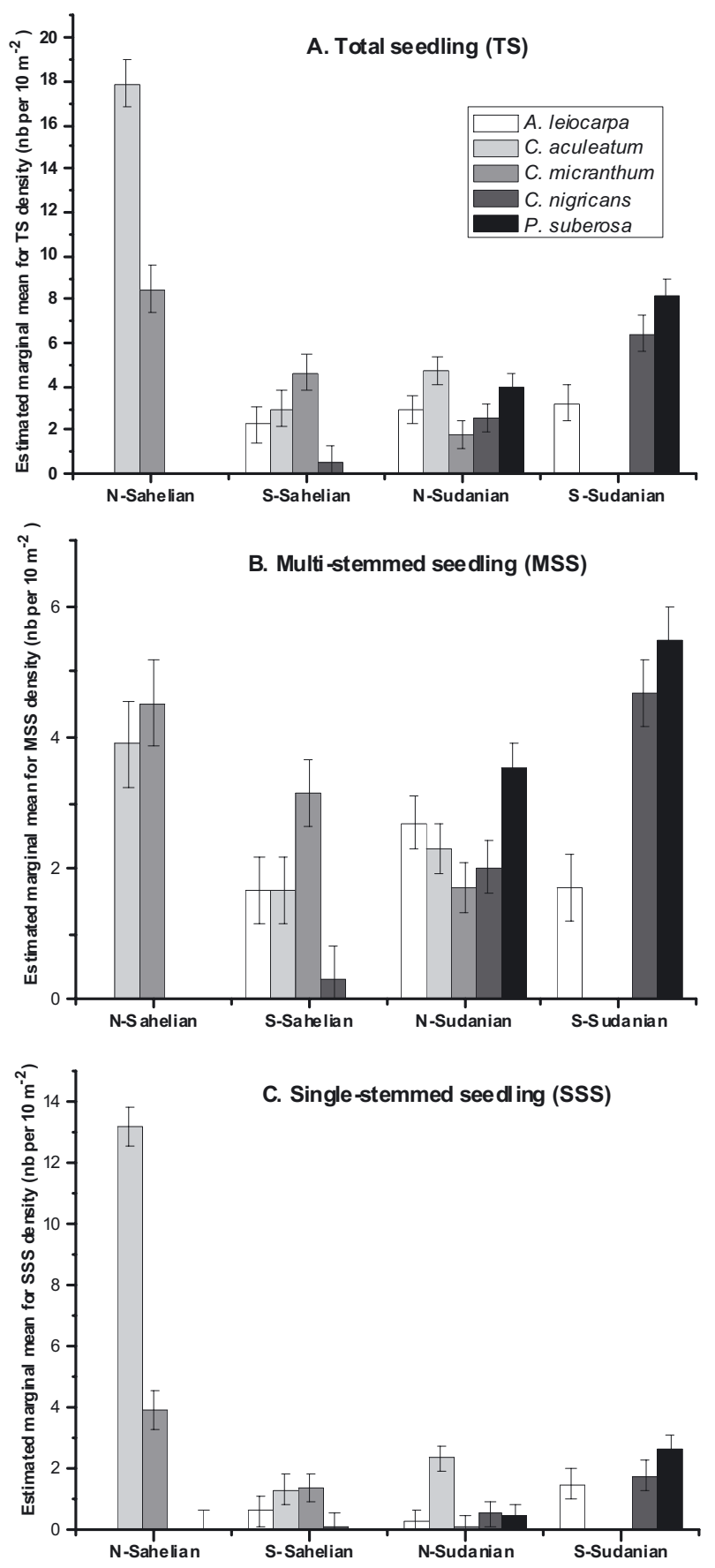

Figure 2. Density of overall seedling populations, multi- and singlestemmed seedlings of five Combretaceae species across a latitudinal gradient in Burkina Faso (mean $\pm \mathrm{SE}$ ).

The most important contribution of true seedling was in the population of $C$. aculeatum (65\%) followed by C. micranthum (19\%) and A. leiocarpa (6\%). Root suckering was the main regeneration mechanism for $P$. suberosa with $96 \%$ contribution while it was almost non-existent in other species. Layering was observed in the populations of $C$. micranthum (10\%) and C. nigricans (1\%). Coppicing was the sec-
Table III. Effects of latitudinal position, species and interaction on the proportion of sexual and asexual recruits of five Combretaceae species in Sahelo-Sudanian zone, Burkina Faso.

\begin{tabular}{lcccccc}
\hline & \multicolumn{4}{c}{ Sexual } & & \multicolumn{2}{c}{ Asexual } \\
\cline { 2 - 4 } \cline { 6 - 7 } & df & $\mathrm{F}$ & $\mathrm{P}$ & & $\mathrm{F}$ & $\mathrm{P}$ \\
\hline Site & 3 & 0.146 & 0.930 & & 0.178 & 0.909 \\
Species & 4 & 1.322 & 0.317 & & 0.932 & 0.478 \\
Sites $\times$ Species & 12 & 28.77 & $<0.001$ & & 20.118 & $<0.001$ \\
Error & 2285 & & & & & \\
\hline
\end{tabular}

ond most important regeneration mechanism for A. leiocarpa $(37 \%)$ and C. micranthum (26\%) while the other species had very few or no coppices.

\section{DISCUSSION}

Establishment, survival and growth of seedlings is governed by several biotic and abiotic factors (Fenner and Thompson, 2005). The great importance of rainfall seasonality as well as the amount of annual rainfall and soil types affects obviously the naturally regenerated seedlings in tropical dry forests (Menaut et al., 1995) and particularly at the country level, where a strong south-north rainfall gradient from the Southsudanian zone to the Sahelian and subsequent changes in vegetation has been established (Schmidt et al., 2005). The lack of decreasing rainfall gradient effects on seedling density of the species (except $C$. micranthum) is in agreement with previous studies (Bongers et al., 1999; Frost et al., 1986), which indicated that the distribution patterns of some plant species are poorly correlated to rainfall. In addition to the climatic factors, seedling attrition in Sahelo-Sudanian zone could be attributed to predation, ground fires and pathogens that are major factors that affect seedling survival and seedling population densities in dry areas (Hubbell, 1979; Marod et al., 2002). Seedling mortality varies among species, depending on the size and age of seedlings, the softness and palatability of tissues (Kitajima and Fenner, 2000) as well as disturbance intensity and regime, and species specific resilience following cessation of disturbance. It should be noted that the Sahelo-Sudanian zone is often subjected to various forms of disturbance such as fire, grazing as well as wood cutting and climatic stress. Except the North-Sudanian sector, not all species regenerated at all sites, which could be related to paucity of seeds, as evidenced from the scarcity of mature trees at the sites (personal observation) in the one hand and the ability to survive repeated die back. Seedling resprouting after dry season die back has been observed as a persistent strategy of dry forest species, with notable inter-specificity (Ky-Dembele et al., 2007). We also observed that some plots were dominated by bushes and grasses, which might have a negative impact on seedling establishment via competition (Vieira and Scariot, 2006). The inter-specific variation in seedling density could be related to complex interaction among species specific characteristics, soil, climatic conditions and regeneration mechanisms including seeds in seed banks as well as their ability to resprouting. 

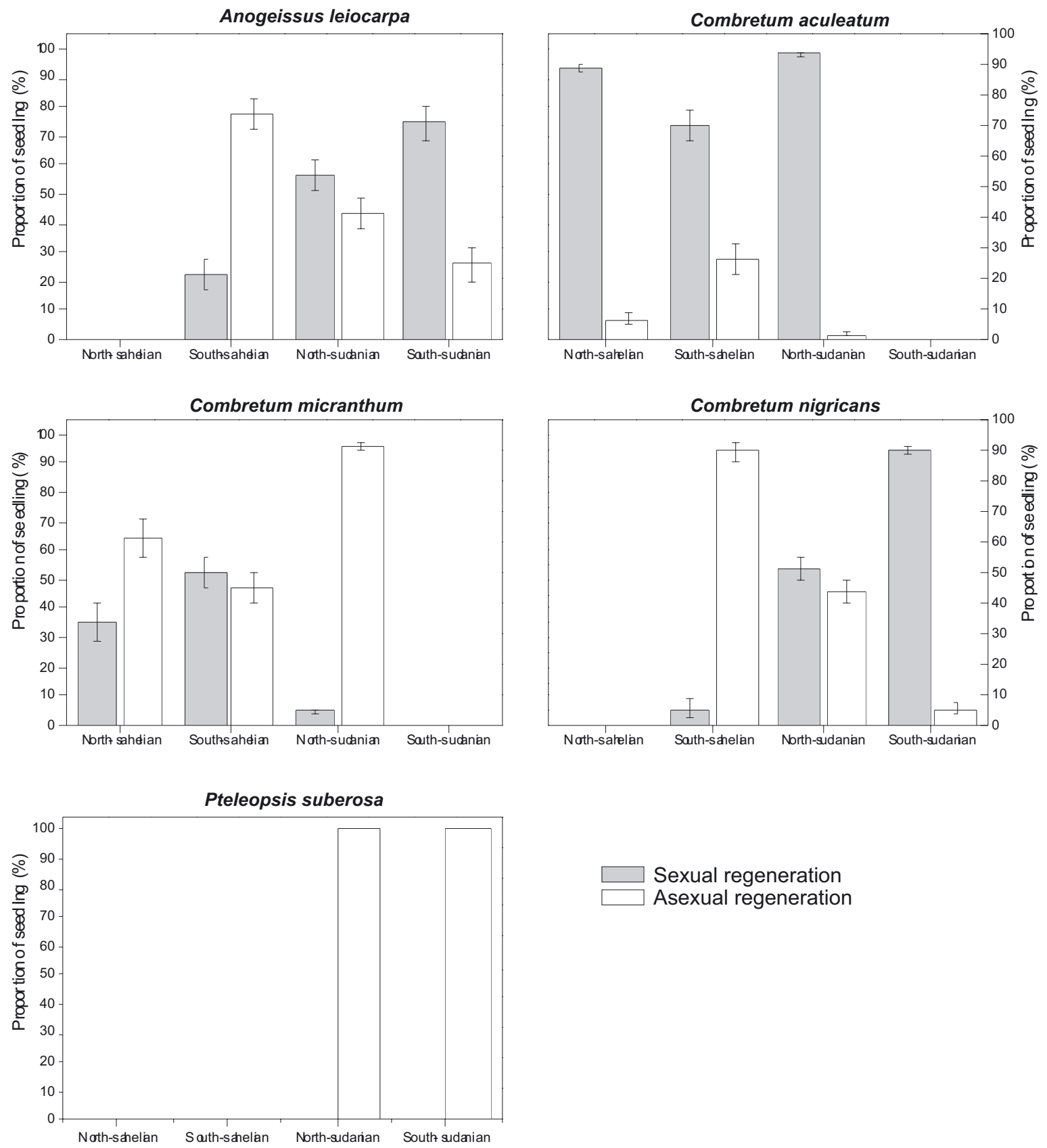

Sexual regeneration Asexual regeneration

Figure 3. The proportion of sexual and asexual recruits along a latitudinal gradient in Burkina Faso, West Africa (mean \pm SE).

Table IV. Effects of latitudinal position, species and their interaction on the relative importance of different regeneration mechanisms of five Combretaceae species in the Sahelo-Sudanian zone, Burkina Faso.

\begin{tabular}{|c|c|c|c|c|c|c|c|c|c|c|c|c|c|}
\hline \multirow{2}{*}{ Factor } & \multirow{2}{*}{ d.f. } & \multicolumn{2}{|c|}{ True seedling } & \multicolumn{2}{|c|}{ Seedling sprout } & \multicolumn{2}{|c|}{ Coppice } & \multicolumn{2}{|c|}{ Water sprout } & \multicolumn{2}{|c|}{ Layer } & \multicolumn{2}{|c|}{ Sucker } \\
\hline & & $F$ & $P$ & $F$ & $P$ & $F$ & $P$ & $F$ & $P$ & $F$ & $P$ & $F$ & $P$ \\
\hline Site & 3 & 0.880 & 0.479 & 0.131 & 0.940 & 2.030 & 0.163 & 1.389 & 0.294 & 0.981 & 0.434 & 1.000 & 0.426 \\
\hline Site $\times$ Species & 12 & 14.465 & $<0.001$ & 23.283 & $<0.001$ & 4.154 & $<0.001$ & 11.557 & $<0.001$ & 29.112 & $<0.001$ & 23.361 & $<0.001$ \\
\hline Error & 2285 & & & & & & & & & & & & \\
\hline
\end{tabular}



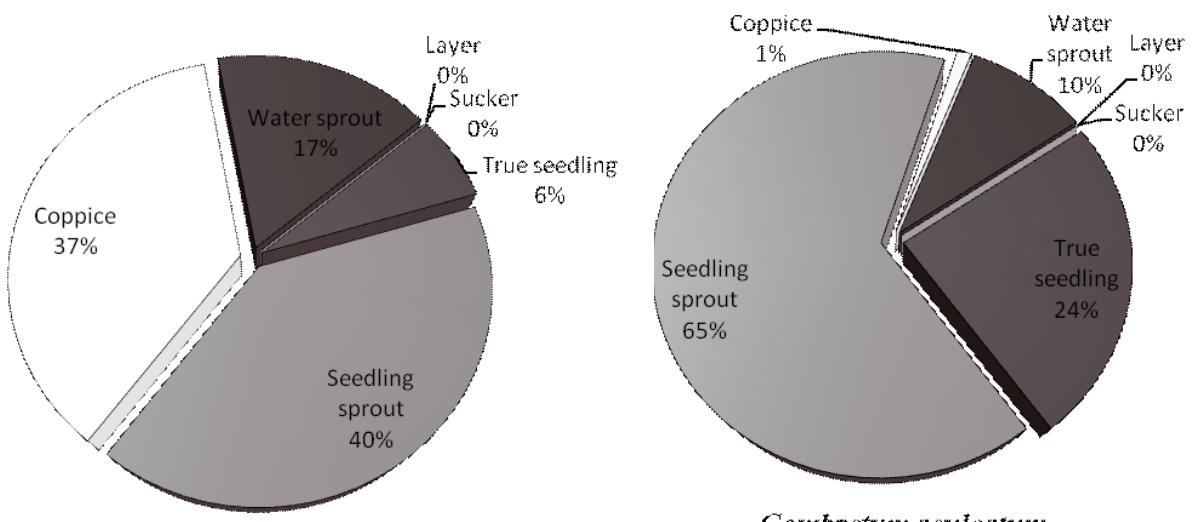

Combretumachleatum

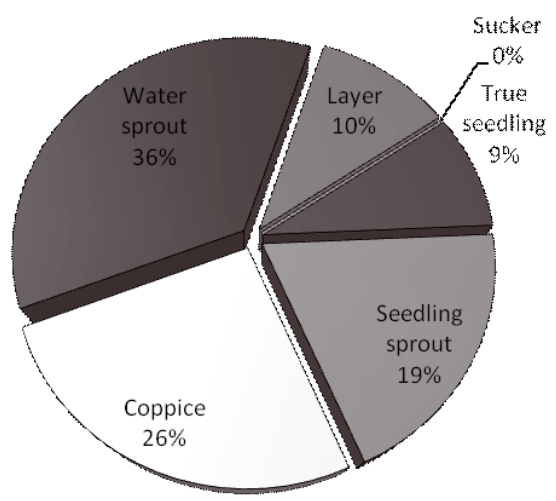

Combretum nicranthum
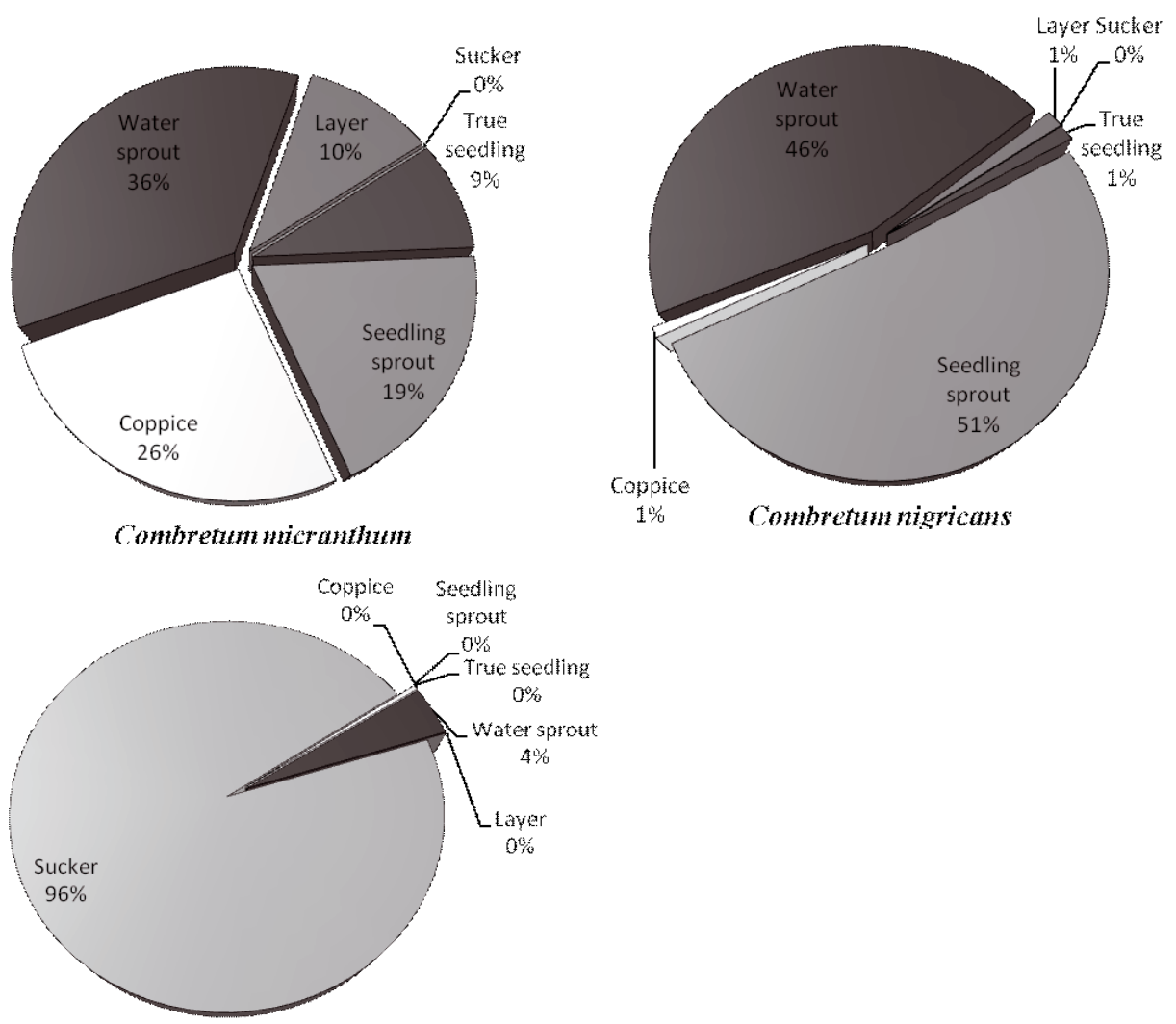

Pteleopsis suberosa

Figure 4. The relative importance of different regeneration mechanisms for the recruitment of five Combretaceae species in Burkina Faso.

The mechanism of regeneration varied with respect to species and latitudinal gradient. This is consistent with previous studies showing species disparity in regeneration along an environmental gradient (Bellefontaine, 2005). The contribution of true seedlings was found to be less than $50 \%$ for all the species, probably because of losses of seeds and young seedlings for predation and site-related limitation for seed germination and seedling recruitment (Kozlowski, 2002; Thiombiano et al., 2003). These losses could be attributed to seed aging, failure of seed to germinate and drought stress as observed elsewhere (Osunkoya, 1994). P. suberosa, and A. leiocarpa had low numbers or no true seedlings at some of the sites primarily due to a large proportion of infertile ovules (Kambou and Guinko, 1995), resulting in poor seed germination (Dayamba et al., 2008). The seeds of $C$. nigricans and C. micranthum are reported to be highly infested by insects (Thiombiano, 2005), which in turn could explain the low or absence of their true seedlings at some of the sites. Among the sexual regeneration mechanisms, the contribution of seedling sprout to the seedling population was important which is consistent with the view that seedling sprouting is a persistence strategy of savanna-woodland species (Ky-Dembele et al., 2007). The large variation in contribution of different regeneration mechanisms to overall seedling population density 
suggests that species seem to have evolved adaptive strategies with regard to environmental conditions induced by latitudinal gradient. This trend may also suggest partly that the environmental conditions at the low latitudinal position are more favorable for seedling from seed origin establishment than the highest latitude.

The asexual regeneration varies with respect to latitudinal gradient and species. This differential response of individual species could be explained by the differences in their biology and ecology, such as coppicing and suckering abilities (Bellefontaine, 2005), as well as their resilience to varying environmental conditions. Seedlings from asexual regeneration have relatively high survivorship in relatively harsh environmental condition in comparison with seedlings from sexual regeneration (Kitajima and Fenner, 2000) since they depend on the already established root system of the original trees for accessing water and nutrient. This might explain the important contribution of the vegetative reproduction in the Sahelian sector. However this situation could not be generalized to all species as evidenced from the substantially high proportion of asexual regeneration for $C$. micranthum at the north Sudanian sector.

Coppices and water sprouts were also relatively important for all the studied species. This is in agreement with several lines of evidence that indicate the importance of the sprouting ability of woody species in tropical woodlands (Kozlowski, 2002; Ky-Dembele et al., 2007; Luoga et al., 2004). C. micranthum coppices profoundly compared to other mechanisms of regeneration. The fact that this species has a high ability to produce coppices suggests a potential of fostering its regeneration by stems cutting. Root suckering was the main mechanism of regeneration of $P$. suberosa which is in agreement with Ky-Dembele et al. (2007). Root suckers of this species were occurred in the Sudanian sector, which has a better environmental condition than the Sahelian sector. This could be an adaptive strategy to cope with frequent disturbance that induces suckering as well as climate conditions. The contribution of layering was found in the populations of $C$. micranthum and $C$. nigricans to a small extent. This result is consistent with earlier studies that showed layering as less important regeneration mechanism in savanna woodlands (Bationo et al., 2005; Bellefontaine, 2005; Karim, 2001; Ky-Dembele et al., 2007).

\section{CONCLUSION}

The results from the present study show that seedling population and regeneration mechanisms vary among species and along the latitudinal gradient. The significant interaction observed between species and latitudinal position highlights the importance of accurate species-site matching to ensure successful restoration of degraded areas in the Sahelo-Sudanian zone. Inter-species differences in regeneration mechanism could be related to their biology and ecological adaptation to the site-specific biotic and abiotic factors. From a management perspective, these results suggest that the restoration of deforested and degraded areas in the Sahelo-Sudanian zone could be achieved by favoring the species and regeneration mechanism that best suit each phytogeographical site.

Acknowledgements: We acknowledge financial support from the Swedish International Development Cooperation Agency (Sida). We thank local people for their assistance and cooperation. Thanks are due to Koundaba Alou, Koudaba Ouseini, Nouma Nalo Albert, Zerbo Moussa and Lamien Donfoui Ignace for their help during the fieldwork. Anonymous reviewers are greatly appreciated for providing valuable and constructive comments on the manuscript.

\section{REFERENCES}

Bationo B.A., Karim S., Saadou M., Guinko S., Ichaou A., and Bouhari, A., 2005. The terrestrial layering: An economical propagation technique for certain tropical woody species. Sécheresse 16: 309-311.

Bellefontaine R., 2005. Sexual reproduction is not the only way for a lot of woody trees: Analysis of 875 cases - Introduction, table and bibliography. Sécheresse 16: 315-317.

Bongers F., van Rompaey R.S.A.R., and Parren M.P.E., 1999. Distribution of twelve moist forest canopy tree species in Liberia and Côte d'Ivoire: response curves to a climatic gradient. J. Veg. Sci. 10: $371-382$.

Catinot R., 1994. Managing wooded African savannas. Such a goal now appears achievable. Bois For. Trop. 241: 53-69.

Ceccon E., Huante P., and Rincón E., 2006. Abiotic Factors Influencing Tropical Dry Forests Regeneration. Braz. Arch. Biol. Technol. 42: $305-312$.

Cohen J., 1988. Statistical power analysis for the behavioral sciences. Lawrence Erlbam, Hillsdale, New Jersey, 567 p.

Crawley M.J., 2005. Statistics: an introduction using R. John Wiley \& Sons, Chister, England, 327 p.

Dayamba S.D., Tigabu M., Sawadogo L., and Oden P.C., 2008. Seed germination of herbaceous and woody species of the Sudanian savannawoodland in response to heat shock and smoke. For. Ecol. Manage. 256: 462-470.

Driessen P., Deckers J., and Spaargaren O., 2001. Lecture notes on the major soils of the world. Food and Agriculture Organization of the United Nations, Rome, 334 p.

Fenner M. and Thompson K., 2005. The ecology of seeds. Cambridge University Press, Cambridge, UK, $250 \mathrm{p}$.

Fontes J. and Guinko S., 1995. Carte de la végétation et de l'occupation du sol du Burkina Faso. Ministère de la Coopération Française : projet campus (88 313 101), $67 \mathrm{p}$.

Frost P., Medina E., Menaut J.C., Solbrig O.T. Swift M., and Walker B., 1986. Responses of savannas to stress and disturbance. A proposal for a collaborative programme of research. IUBS-UNESCO-MAB, Biology International, Special issue 10, 82 p.

Gaston J.K., 2007. Latitudinal gradient in species richness. Curr. Biol. 17: 574.

Hawkins B.A., Field R., Cornell H.V., Currie D.J., Guegan J.F., Kaufman D.M. Kerr J.T., Mittelbach G.G., Oberdorff T., O'Brien E.M., Porter E.E., and Turner J.R.G., 2003. Energy, water, and broad-scale geographic patterns of species richness. Ecology 84: 3105-3117.

Hubbell S.P., 1979. Tree Dispersion, abundance, and diversity in a tropical dry forest. Science 203: 1299-1309.

Kambou S. and Guinko S., 1995. La fleur et l'inflorescence de Anogeissus leiocarpus (DC.) Guill. et Perr. Acta biol. Benrodis 7: 163-173.

Karim S., 2001. Contribution à l'étude de la régénération par multiplication végétative naturelle de deux combretacées dans l'ouest du Niger (Combretum micranthum G. Don et Guiera senegalensis J.F. Gmel) : conséquences pour une gestion sylvopastorale. DEA, Université de Ouagadougou, 58 p. 
Khurana E. and Singh J.S., 2001. Ecology of seed growth for conservation and restoration of tropical dry forest: a review. Environ. Conserv. 28: $39-52$.

Kitajima K. and Fenner M., 2000. Ecology of seedling regeneration. In: Fenner, M. (Ed.), The ecology of regeneration of plant communities. CABI Publishing, Wallingford, pp. 331-359.

Kozlowski T.T., 2002. Physiological ecology of natural regeneration of harvested and disturbed forest stands: implications for forest management. For. Ecol. Manage. 158: 195-221.

Ky-Dembele C., Tigabu M., Bayala J., Ouedraogo S.J., and Oden, P.C., 2007. The relative importance of different regeneration mechanisms in a selectively cut savanna-woodland in Burkina Faso, West Africa. For. Ecol. Manage. 243, 28-38.

Luoga E.J., Witkowski E.T.F., and Balkwill K., 2004. Regeneration by coppicing (resprouting) of miombo (African savanna) trees in relation to land use. For. Ecol. Manage. 189: 23-35.

Marod D., Kutintara U., Tanaka H., and Nakashizuka T., 2002. The effects of drought and fire on seed and seedling dynamics in a tropical seasonal forest in Thailand. Plant Ecol. 161, 41-57.

Menaut J.C., Lepage M., and Abbadie L., 1995. Savannas, woodlands and dry forests in Africa. In: Bullock, S.H., Mooney, H.A., and Medina, E.E. (Eds.), Seasonally dry tropical forests, Cambridge University Press, England. pp. 64-92.

Moles A.T., Warton D.I., Stevens R.D., and Westoby M., 2004. Does a latitudinal gradient in seedling survival favour larger seeds in the tropics? Ecol. Lett. 7: 911-914.

Osunkoya O.O., 1994. Postdispersal survivorship of North Queensland rainforest seeds and fruits: effects of forest, habitat and species. Aust. J. Ecol. 19: 52-64

Poorter L. and Markesteijn L., 2008. Seedling traits determine drought tolerance of tropical tree species. Biotropica 40: 321-331.

R Development Core Team 2006. R: A language and environment for statistical computing. R Fondation for Statistical computing, Vienna, Austria.

Schemske D.W., 2002. Ecological and evolutionary perspectives on the origins of tropical diversity. In: Chazdon R. and Whitmore T. (Eds.),
Foundations of tropical forest biology: classic papers with commentaries, University of Chicago Press, Chicago, IL, pp. 163-173.

Schmidt M., Kreft H., Thiombiano A., and Zizka G., 2005. Herbarium collections and field data-based plant diversity maps for Burkina Faso. Divers. Distrib. 11: 509-516.

Slot M. and Poorter L., 2007. Diversity of tropical tree seedling responses to drought. Biotropica 39: 683-690.

Stevens G.C., 1989. The latitudinal gradient in geographical range: how so many species coexist in the tropics. Am. Nat. 133: 240-256.

Thiombiano A., 2005. Les Combretaceae du Burkina Faso : taxonomie, écologie et régénération des espèces. Thèse d'Etat, Université de Ouagadougou, $290 \mathrm{p}$.

Thiombiano A., Wittig R., and Guinko S., 2003. Conditions of sexual multiplication in some Combretaceae in Burkina Faso. Rev. Ecol. (Terre Vie) 58: 361-379.

Vázquez-Yanes C. and Orozco-Segovia A., 1993. Patterns of seeds longevity and germination in the tropical rainforest. Annu. Rev. Ecol. Syst. 24: 69-87.

Vieira D.L.M. and Scariot A., 2006. Principle of natural regeneration of tropical dry forests restoration. Restor. Ecol. 14: 11-20.

Weltzin J.F. and McPherson G.R., 1999. Facilitation of conspecific seedling recruitment and shifts in temperate savanna ecotones. Ecol. Monogr. 69: 513-534.

Willig M.R., Kaufman D.M., and Stevens R.D., 2003. Latitudinal gradients of biodiversity: pattern, process, scale, and synthesis. Annu. Rev. Ecol. Syst. 34: 273-309.

Zida D., Sawadogo L., Tigabu M., Tiveau D., and Oden P.C., 2007. Dynamics of sapling population in savanna woodlands of Burkina Faso subjected to grazing, early fire and selective tree cutting for a decade. For. Ecol. Manage. 243: 102-115.

Zida D., Tigabu M., Sawadogo L., Tiveau D., and Odén P.C., 2009. Longterm effects of prescribed early fire, grazing and selective tree cutting on seedling populations in the Sudanian savanna of Burkina Faso. Afr. J. Ecol. 47: 97-108. 